\title{
Die teodiseevraag: 'n Antwoord vanuit 'n pastorale perspektief
}

\author{
Petri de Kock \& J H Koekemoer \\ Departement Dogmatiek en Christelike Etiek (Afd A) \\ Universiteit van Pretoria
}

\begin{abstract}
The problem of theodicy: An answer from a pastoral perspective

A fundamental aspect of the problem of theodicy is the experience of God's action as at times unfair, a perception at home especially in a situation of human suffering. God's redemptive action in and through his Son Jesus Christ, however, opens a new perspective on this problem. In faith, God is not a distant God any more. He entered into the problematic situation of human suffering, bringing redemption to man.
\end{abstract}

\section{INLEIDING}

Gelowiges word dikwels met die teodiseevraag gekonfronteer. Hierdie vraagstelling veronderstel onder andere dat God se handelinge met mense onbegryplik is. Hierdie handelinge van God word soms bevraagteken, veral vanweë die vermoede dat dit onregverdig is. Daar word onder andere na Job as vroom en opreg verwys; iemand wat God gedien en die kwaad vermy het. Tog word Job deur die loop van die geskiedenis die staande voorbeeld van 'n mens wat deur God gekasty is, terwyl hy dit, so word gestel, geensins verdien het nie (vgl Job 1:1; 2:11-13).

Die belewenis van die onbetrokkenheid van God tree ook telkens in lydingsituasies op die voorgrond (vgl Ps 10:1). God word as afwesig beleef. 'n Mens word dikwels oorweldig deur die skynbare onbedagsaamheid van God (Komp 1992:69). Predikante twyfel soms hoe hulle daarin kan slaag om mense tot geloof in God aan te moedig as hulleself meer vrae as antwoorde in die opsig het. Verder moet gelowiges teenoor mekaar erken dat hulle verstaan van God, hulle Godsbegrip aan die een kant, en hulle lewenservaring aan die ander kant, onder andere die belewenis van die sinloosheid van lyding, nie aldag met mekaar te rym is nie. Hoe rym 'n mens God se eienskappe van liefde, genade en barmhartigheid met al die siekte, pyn en lyding in die wêreld?

* Hierdie artikel is 'n verwerking van die resultate van die $\mathbf{M}$ Div-skripsie, ingedien en aanvaar as deel van die vereistes vir die M Div-graad (1997), Departement Dogmatiek en Christelike Etiek, Fakulteit Teologie (Afd A), Universiteit van Pretoria, onder leiding van prof dr J H Koekemoer. 
Voorbeelde van lyding is natuurlik nie slegs tot gelowiges beperk nie - alle mense gaan daaronder gebuk. Die verskil is egter, sonder geloof in God tree hierdie worstelstryd nie na vore nie en bly dit gewoonlik 'n blote uitroep van verslaentheid (Ott 1981: 219). Dit is die gelowige wat in tye van lyding en siekte deur diepe aanvegting gaan, want hy leef in die vaste oortuiging dat God met die mens bemoeienis maak. Daarom laat negatiewe ervarings die gelowige dikwels vrae vra wat direk met God in verband staan: 'Straf God my dalk vir iets wat ek verkeerd gedoen het?'.

\section{PROBLEEMSTELLING}

Vanuit die voorafgaande opmerkings word nou oorgegaan na 'n poging tot die formulering van 'n probleemstelling. Die teodiseevraag val oënskynlik in twee dele uiteen: Godsbewys en Goddelike betrokkenheid of ingrype in die skepping. Ten opsigte van die eerste deel het Gottfried Wilhelm Leibniz, volgens Broad (1975:148-159), soos ander denkers van die sewentiende eeu, eers die bestaan van God probeer bewys voordat hy oorgegaan het na teologiese argumentasie. Hierdie praktyk word nie meer deur hedendaagse teoloë gevolg nie (vgl Ott 1974:29-39). Die huidige paradigma veronderstel dat God nie objektiveerbaar is nie en daarom ook nie bewysbaar is nie. Indien daarop aanspraak gemaak word dat die bestaan van God bewys is, kan met reg gevra word of dit nog die God van die Bybel is wat ter sprake is.

Hierdie deel van die probleem word derhalwe vir die doeleindes van hierdie skripsie buite rekening gelaat. In ' $n$ regverdiging van so 'n besluit, kan verwys word na 'n stelling van Heinrich Ott (1974:79-89) waarin hy konkludeer dat 'n gesprek oor God, 'n gesprek met God impliseer. So 'n uitgangspunt plaas die vraag na die bewysbaarheid van God, buite die konteks van die argument binne hierdie skripsie.

Ten opsigte van die tweede deel het Leibniz in sy werk Théodicée, volgens Broad (1975:5), op 'n breedvoerige wyse God se handelinge met die mens probeer regverdig. Dit is wat die woord teodisee wil sê. Dit is immers afgelei van die Griekse woorde theos (God) en dikaios (regverdig) (Weiland 1955:690). Teologies gesien gaan dit in die teodisee om die regverdiging van God se beheer van sy skepping. Dit is 'n menslike poging om bewys te lewer dat God se regering van die wêreld, ten spyte van alle raaiselagtigheid, tog heilig, goed en regverdig is. Dit is 'n poging om die sinvolheid van God se handelinge in die wêreld en in die menslike lewe aan te dui en Hom as't ware só teen elke aanklag te verdedig (Berkouwer 1950:276).

As daar oor God se regering van die wêreld gepraat word, tree die vraag na menslike vryheid vanselfsprekend ook na vore. In welke mate is die mens vry om sy eie lewe te lei, om keuses en beslissings uit te oefen? Leibniz (1951:123) ag menslike vryheid noodsaaklik, omdat daarsonder nie van skuld en straf sprake kan wees nie. Hy 
neem hierdie standpunt in teenoor 'n tydgenoot Bayle (Leibniz 1951:58) wat in die rigting van die ontkenning van selfstandige handelinge deur die mens neig.

'n Verdere vraag wat na vore tree is dié na die verhouding tussen Goddelike regering en menslike vryheid. Kan die mens wat sy vryheid korrek aanwend, seën en voorspoed te wagte wees? Kan die mens wat sy vryheid misbruik, ellende en teëspoed te wagte wees? Is die mens hoegenaamd in staat om deur selfstandige handelinge, God in enige rigting te beweeg? Hierdie vrae is vir die pastoraat van belang, aangesien gelowiges wat onder siekte en lyding gebuk gaan, dikwels oor die wyse van God se betrokkenheid in hulle nood, wonder of selfs twyfel.

Volgens Pannenberg (1991:37) is een van die grootste probleme van die Christelike geloof, om 'n relasie tussen God en die wêreld van natuur en geskiedenis aan te dui. Anders gestel: Dit is moeilik om 'n denkbeeld van die wêreld te vorm as synde afhanklik van God. Dit is juis wat die moderne wetenskap volgens hom gedoen het dit het die bande van afhanklikheid van God losgemaak. Die begrip God en ook God self raak oorbodig as wêreldgebeure en dit wat in die natuur plaasvind, nie meer in relasie met God se handelinge gebring kan word nie. Die voortgaande aktiwiteit van die Skeppergod het so in gedrang gekom.

Wanneer Van Wyk (1988:451) na Pannenberg verwys, stel hy dat die God-is-dood teologie - wat van die veronderstelling uitgaan dat God in die moderne kultuur afwesig is - op teologiese waninformasie berus. Hierdie teologie verstaan onder die afwesigheid van God, die irrelevansie of funksieloosheid van God vir 'n moderne wêreldverstaan. Hierdie sogenaamde oorbodigheid van God kan nooit beteken dat God nie in hierdie wêreld handelend met die mens omgaan nie (Van Wyk 1988:451).

Die vraag is egter: 'Hoe handel God met die mens?' Die vraag tree veral in menslike nood na vore. Dan word gewoonlik met die volgende sake geworstel:

* Die skynbare afwesigheid van God;

* die belewenis van lyding en siekte as straf van God;

* die totale uitsigloosheid in die aangesig van lyding en die dood.

Op bogenoemde sake is daar al verskillende antwoorde gegee. Sommige daarvan sal ook in hierdie skripsie aan die orde kom. Vanweë die beperkte omvang van die studie, sal ná 'n bespreking van die probleem, egter slegs na die kruisteologie verwys word as 'n moontlike antwoord op die vraag na menslike nood. Die studie pretendeer nie om 'n volledige gesprek en antwoord op die teodiseevraag te gee nie, maar poog eerder om vanuit 'n bepaalde perspektief, in hierdie geval, 'n pastorale perspektief soos dit in die kruisteologie na vore tree, lig op die saak te werp. 


\section{ONTKNOPING VAN DIE PROBLEEM}

\subsection{Die wysheidsliteratuur}

Die wysheidsliteratuur in die Bybel lewer ' $n$ bepaalde bydrae tot die ontrafeling van die teodiseeprobleem, in dié opsig dat dit 'n soeke na sin en samehang in die wêreld en in die lewe veronderstel. Dit probeer 'n antwoord gee op die vraag waarom sommige mense geluk en voorspoed beleef en ander lyding en teëspoed.

Kenmerkend van hierdie literatuur is die opvatting dat daar ' $n$ basiese orde in die skepping is wat deur God daargestel is (Loader 1989:684). Wysheid beteken dat 'n mens hierdie orde leer ken en dienooreenkomstig sal lewe. Die wysheidsleraars van Israel het geglo dat hulle hierdie orde en die manier waarop dit werk, kon herken. Hulle het verder aanvaar dat hulle riglyne kan opstel aan die hand waarvan mense by hierdie orde kan inskakel om in harmonie daarmee te lewe (Loader 1989:684). As iemand hierdie riglyne navolg toon hy daardeur dat hy God se gesag aanvaar deur by sy orde in te skakel. So 'n persoon leef in harmonie met die Goddelike orde en daaruit spruit vir hom goeie gevolge voort; hy is 'n wyse mens en word vir sy wysheid beloon met voorspoed en sukses. Die mens wat hierdie voorskrifte nie nakom nie, weerstaan God se orde en daarmee saam sy gesag. So 'n persoon leef in disharmonie met die Goddelike orde en daaruit spruit vir hom slegte gevolge voort; hy is 'n dwaas en word vir sy dwaasheid vergeld met teëspoed en mislukking (Loader 1989:685).

Bogenoemde word gewoonlik die optimistiese inslag van die wysheid genoem en het tot die belonings- en vergeldingsgedagte aanleiding gegee (Loader 1989:684). Hierdie optimistiese wysheid - wat hoofsaaklik in die Spreukeboek voorkom - was verantwoordelik vir 'n krisis, want volgens Van Wyk (1988:454) was dit dikwels die geval dat gelowiges deur die loop van die geskiedenis aan hierdie samehange getwyfel het; 'n gelowige kon dikwels geen grond vir sy lyding vind nie, geen relasie tussen sy doen en sy lot in die lewe vasstel nie.

Veral Job en Prediker het eintlik in reaksie op hierdie soort wysheid tot stand gekom (Blank 1962:858). Die skrywers van hierdie boeke het agtergekom dat daar baie mense is wat reg en goed lewe, wat met ander woorde by God se orde inskakel, en tog beleef hulle teëspoed en ellende. Job self was immers 'n goeie voorbeeld van so 'n mens (vgl Job 1:1; 2:11-13). Die skrywers van Job en Prediker was diep bewus daarvan dat die mens meer gekompliseerd is en dat God inderdaad minder deursigtig is as wat die optimistiese wysheid wou voorgee (Blank 1962:858). Volgens Van Wyk (1988:455) gaan Prediker uit van die verborgenheid van God wat herlei kan word na sy onbegryplike gelukstoedelings aan mense. Volgens Prediker is God nie manipuleerbaar op grond van menslike gesindhede nie, want Hy bepaal op onbegryplike wyse die lot van goeies en slegtes (Van Wyk 1988:456). 
Job en Prediker kom eintlik tot die slotsom dat sukses en voorspoed nie gewaarborg kan word as die mens by God se orde inskakel nie. Hierdie boeke dui die beperkings aan van die mens se vermoë om sy eie lewe volledig te beheer; sekere terreine behoort aan God alleen; nie alle gebeure kan deur die mens voorsien word nie. Menslike erkenning van hierdie beperkings wat God op sy lewe geplaas het, lei tot nederigheid, seker die mees uitstaande kenmerk van 'n wyse mens (Clements 1983:136).

Van Selms (1983:70) is van oordeel dat die hoekoms en waaroms in die lewe altyd daar sal wees; die redes vir sekere gebeurtenisse - onder andere ernstige siekte en lyding - sal altyd vir mense duister bly, want dit is God se saak. Van mense word egter verwag om - ongeag voorspoed of teëspoed, gesondheid of siekte - God met eerbiedige ontsag te gehoorsaam en om alles te vermy wat nie volgens sy wil is nie (vgl Job 28:28).

\subsection{Die oorsprong van lyding en kwaad}

Aan die einde van die skeppingsverhaal in Genesis 1:31 word verhaal dat God na alles gekyk het wat Hy gemaak het, en dit was baie goed. En tog is daar die skynbaar sinlose lyding van skepsels en die ten minste tydelike sukses van die bose in die wêreld. Hierdie feit plaas 'n vraagteken agter 'n Skepper wat beide almagtig en goed is (Pannenberg 1994:162). Die vraag wat gewoonlik gestel word, is: 'Hoe kan 'n almagtige, alwetende en goeie God toelaat dat skepsels ly en dat die kwaad opsetlik gedoen word?' (Ott 1981:219).

Selfs al was daar geen samewerking van die kant van God in die kwaad wat plaasvind nie, bly die raaiselagtige nog steeds dat Hy die kwaad kon voorsien het, en dat alhoewel Hy dit deur sy almag kon verhoed het, Hy dit nogtans toelaat (Leibniz 1951: 58). Volgens Ott (1981:220) beteken hierdie trant van redenasie dat God vooruit van die kwaad moes geweet het en dit dus vooruit gewil het of dit ten minste toegelaat het. Vir Ott is ' $n$ bewustelike toelating in wese reeds 'n wil daartoe. Die onvermydelike gevolg is die gedagte dat God die bewerker van die kwaad is. So 'n opvatting weerspreek egter die Christelike verstaan van God.

'n Ander standpunt in hierdie verband is dié van die dualisme. Hierin bestaan daar naas God as die goeie grondbeginsel, in gelyke mate as God, 'n bose grondbeginsel. Hierdie opvatting is moontlik waar die Skepper van die wêreld nie as die Vader van Jesus Christus gesien word, wat inderdaad vir sy skepping teen die bose stry en wat ook daaroor mag het nie (Ott 1981:221). Binne die reformatoriese kerk is soms gekies vir 'n monistiese standpunt: Geen outonome mag word aan enige god, persoon of instansie toegeken, naas die Drie-enige God soos in die Skrif geopenbaar nie. Hierdie standpunt tree onder andere ook in die Heidelbergse Kategismus na vore (vgl HK vr 27, 28; NGB art 13). 
Die godsdiens van Israel en van die vroeë Christendom wou nooit so ver gaan om die Skepper te verdink van die bose wat die skepping binnegedring het nie (Pannenberg 1994:163). Dit was omdat die mens aan die een kant as die verantwoordelike gesien is; aan die ander kant is daar geglo dat die skepsel geen reg het om homself as regter oor God aan te stel nie (vgl Jes 45:9; Jer 18:6; Rom 9:20).

Die probleem raak akuut as Pannenberg (1994:166) daarop wys dat die Skepper nie van verantwoordelikheid ten opsigte van die koms van die kwaad ontneem kan word nie, omdat die oorsprong van die bose in die keusevryheid van die mens lê. Volgens hom is skepsels wel vry, maar hulle bly nogtans God se skepsels, wat God met ander woorde medeverantwoordelik hou. Die opvatting oor die vryheid van skepsels bevat 'n belangrike element van waarheid, want as die Skepper vry en onafhanklike skepsels wou gehad het, wat sy Goddelikheid spontaan kon erken, dan moes Hy ook die risiko loop van 'n skepsel wat sy vryheid kon misbruik. So gesien, aanvaar die Skepper die moontlikheid van sonde en boosheid as voorwaarde vir die realisering van 'n vrye gemeenskap tussen Hom en sy skepsel. Volgens Pannenberg het God dus nie slegtheid en boosheid as sodanig gewil nie, maar dit is begeleidende verskynsels in die realisering van sy doel met sy skepsel.

Pannenberg (1994:169) stel verder dat die verantwoordelikheid vir die koms van die kwaad in die skepping op God val, wat dit voorsien het en toegelaat het, hoewel menslike handeling die onmiddellike oorsaak daarvan is. Die poging om God van verantwoordelikheid te ontneem, slaag volgens hom nie, omdat dit nie strook met die getuienis van die Nuwe Testament nie: In en deur die kruisiging van sy Seun het God verantwoordelikheid aanvaar vir die wêreld wat deur Hom gemaak is. Dat Pannenberg (1994:172) die mens egter medeverantwoordelik hou, blyk duidelik as hy sê dat die oorsprong van lyding en kwaad, lê in die oorgang van 'n God-gegewe onafhanklikheid na 'n self-gegewe onafhanklikheid, met ander woorde 'n misbruik van die vryheid wat God aan die mens gegee het, die strewe van die mens na 'n radikale onafhanklikheid.

Augustinus (kyk Leibniz 1951:378) het dikwels gesê dat God die bose toegelaat het sodat die goeie, of dit wat beter is, daaruit mag voortkom. Volgens Leibniz (1951: 378) was die val van Adam 'n gelukkige sonde, want daarvoor is vergoed met die geboorte van die Seun van God. In sy Seun het God 'n baie edeler geskenk aan die heelal gegee as wat daar andersins onder geskape wesens sou wees. Leibniz maak daarom die afleiding dat ' $n$ wêreld waarin die kwaad aanwesig is, ' $n$ beter wêreld is as een daarsonder.

Heinrich Ott redeneer net soos Pannenberg, weg van 'n dualisme sowel as 'n suiwer monisme, in 'n dialektiese rigting. Vrae na die oorsprong van lyding en kwaad is volgens Ott (1981:226) teologiese grensvrae, omdat daar nie rasionele verklarings daar- 
voor is nie; dit lei ons eerder in in die ontmoeting met God as Verlosser. Die funksie van sulke grensvrae is dat dit ons direk met die werklikheid van God konfronteer - as mense wat lyding en kwaad moet verduur, maar wat ook self die kwaad doen en dus skuldig staan (Ott 1981:227).

Al was daar oënskynlik 'n oorspronklike toelating van die kwaad deur God, kan saam met Pannenberg (1994:169) gekonkludeer word dat menslike onverantwoordelikheid (bv Auschwitz), nalatigheid (bv ongelukke) en dwaasheid (vgl Spr 19:3), die onmiddellike oorsake van lyding en kwaad is. Op grond van God se almag moet erken word dat $\mathrm{Hy}$ altyd by die mens betrokke is - - ok in sy lyding en siekte - sonder om daardeur te sê dat Hy die outeur van negatiewe gebeure is. Die presiese wyse waarop God by mense in hulle nood betrokke is, is 'n verborgenheid. Die gelowige erken en bely egter - al verstaan hy nie altyd waarom sekere goed moes plaasvind nie - dat God in staat is om alles uiteindelilk ten goede te laat meewerk (Rom 8:28).

\subsection{Regverdiging van God?}

Wanneer Ott (1981:222) na Luther verwys, stel hy dat die teodisee as poging om God te regverdig, onmoontlik is. Hy draai die vraag om, want volgens hom is dit nie God wat regverdiging teenoor mense benodig nie, maar wel die mens wat 'n behoefte het om voor en deur God regverdig verklaar te word. Dit gaan dus nie daarom dat God se eer deur mense gered moet word nie, maar eerder daarom dat die mensdom deur God gered word (Ott 1981:225).

Pannenberg (1994:164) argumenteer dat 'n gebrek in Leibniz se uitwerk van die teodiseeprobleem, is dat hy God uitsluitlik vanuit die oorsprong van die wêreld en op grond van die skeppingsorde probeer regverdig het, sonder om die geskiedenis van God se verlossende handeling in en deur Jesus Christus in berekening te bring. Die oplossing van die probleem van God se regverdigheid, naamlik sy regverdige handelinge met sy skepsels, staan nie in die middelpunt nie, maar wel die openbaring van God se regverdigheid (Ott 1981:225). God openbaar sy regverdigheid daarin dat Hy die goddelose vryspreek (Rom 4:5) op grond van die geloof in die gekruisigde Christus. Die waarom-vraag van die lydende mens word nie deur die openbaring van God se regverdigheid verdring nie, maar in die Christusgebeure opgeneem in so 'n mate dat elke lydende mag glo dat sy lyding en sterwe, in die lyding en sterwe van Christus opgehef is (Ott 1981:225).

God staan in die gekruisigde Christus nie meer as hemelse teenpool teenoor die mens nie, want Hy staan nie meer voor die regbank van die menslike teodiseevraag nie - Hy is nou self daarin verstrengel (Ott 1981:222). Gerig en verdoemenis kom in die 
kruisgebeure op God self neer, deurdat die mens vrykom en lewe. Dit is 'n toekomsontsluitende gebeurtenis, want in die opwekking van die gekruisigde kan 'n voorteken van die Godsryk gesien word, waarin God waarlik God is, en die mens tot vryheid kom. In die Christusgebeure vind die vraag wie God werklik is, sy antwoord. Die beeld van ' $n$ hemelse maghebber wat die mens aankla, word nou deur ' $n$ ander beeld verdring - God blyk nou die mag tot wêreldverandering te wees deur middel van plaasvervangende lyding (Ott 1981:222).

Volgens Van Wyk (1988:453) moet lydendes en sterwendes geleer word om die sonde en sy konsekwensies, asook God se toorn oor die sonde, te ken. Die bitterheid teenoor God en die teleurgesteldheid in Hom, sal volgens hom verminder kan word as hierdie realiteit weer ter sprake gebring word. Die betekenis van die leer oor die sonde lê vir hom daarin dat hierdie leer siekes en gesondes, lydendes en nie-lydendes saambind, want beide is volgens hom in dieselfde mate verlossingsbehoeftig. En God se gerig oor die sonde is voltrek - nie aan die oortreder nie, maar aan Jesus Christus. In die kruis is dus vir die mens die uiterste gerig en uiterste genade ineen geweef (Van Wyk 1988:457). Gerig, want in die kruisgebeure is dit duidelik dat God, as die Heilige, die sonde nie kan duld nie. Genade, want deur die kruisgebeure tree vryspraak vir die mens in werking; hy mag vrykom en lewe op grond van dit wat iemand anders vir hom gedoen het. Genade is nie 'n geestelike krag wat in die mens self aanwesig is nie, maar beteken om deel te kry aan die krag waardeur God mense red.

Alleenlik hierdie vreemde geregtigheid van God sal volgens Van Wyk (1988:458) kan troos, aangesien dit sy toorn oor ons sondige bestaan sien teen die agtergrond van sy grondlose barmhartigheid. Volgens hom moet lydende mense gehelp word om nie die spel van selfregverdiging te speel, en God so van onregverdigheid aan te kla nie, of om God te probeer regverdig deur jouself te verdoem nie. Van Wyk (1988:459) glo hulle moet geleer word om getroos te word, en nie om te regverdig nie. Die enigste geloofsopbouende hantering van hierdie saak lê daarom vir hom daarin dat die samehang van die oersonde en lyding uitgewys sal word.

Op grond hiervan sou ' $n$ mens heeltemal tereg die afleiding kon maak dat daar nie 'n direkte verband tussen 'n bepaalde sonde en 'n siektetoestand gelê kan word nie. Daar sou ook nie gesê kon word dat God lyding oor iemand bring as straf op 'n bepaalde oortreding nie. Lyding en siekte is deel van die gebroke bedeling waarin die mens nog leef. As 'n oorsaak hiervoor gesoek moet word, kan dit hoogstens na die oersonde (sondeval) herlei word - en alle mense gaan onder die gevolge daarvan gebuk, nie slegs siekes en lydendes nie. 
Pannenberg (1994:164) is van mening dat slegs God deur sy uiteindelike ingrype, 'n bevredigende antwoord op die teodiseevraag sal bied. Sonder die hoop op 'n eskatologiese oorwinning oor die werklikheid van sonde en kwaad, kan geen bevredigende antwoord gegee word nie (Pannenberg 1994:173). 'n Antwoord is volgens hom slegs moontlik as ons glo dat die skepping gekoppel is aan die Goddelike werk van versoening en verlossing van die wêreld. Slegs die eskatologiese voltrekking van die wêreld kan daarom onomwonde God se regverdigheid en Goddelikheid bewys.

Ott (1981:226) weer is van oortuiging dat die teodiseevraag 'n onbeantwoordbare vraag, en tog ook 'n noodsaaklike een is. As ' $n$ antwoord wel gewaag moet word, kan dit volgens hom langs verskillende weë gedoen word (Ott 1981:227). Die antwoord van die kruisteologie is dat God self die sinloosheid van lyding en kwaad betree het en dit op Hom geneem het. Die antwoord van die opstandingsteologie is dat God oor die mag beskik om uit die totale sinloosheid van die dood, 'n nuwe begin te skep. Die eskatologiese antwoord is dat ons die laaste dag tegemoetgaan, waar ons die sin van alles in God se lig sal kan verstaan. Die etiese antwoord is dat ons in gehoorsaamheid aan God, voortdurend teen lyding en kwaad sal stry, so asof ons dit volledig kan uitroei.

As Pannenberg (1994:166) se standpunt in gedagte gehou word, dat God in en deur die Christusgebeure verantwoordelikheid vir die wêreld aanvaar het, kan die afleiding gemaak word dat God die teodiseevraag in 'n sekere sin in en deur Christus opgelos het. Nie in die sin dat die raaiselagtigheid of onverklaarbaarheid van sekere gevalle van lyding weggeneem is nie, maar in dié sin dat Hy alle twyfel oor sy goedheid uit die weg geruim het. Deur die Christusgebeure het God getoon dat dit goed is soos Hy regeer. In en deur Jesus Christus het Hy sy solidariteit met menslike nood betoon. Die Christusgebeure is dus ' $n$ openbaring van die Vaderhart - Hy het die mens lief en is daarom selfs bereid om in en deur Christus, saam met en in die plek van die mens te ly.

\section{TROOS}

Om die teodiseevraag vanuit ' $n$ pastorale perspektief te benader, impliseer dat dit wat met pastorale bewoënheid te doen het, op die voorgrond behoort te tree. Uit die ondersoek tot hiertoe is dit duidelik dat die redes vir sekere gebeurtenisse altyd vir mense duister is, omdat dit God se saak is (Van Selms 1983:70). Hierdie erkenning van menslike beperktheid ten opsigte van insig in die redes vir sekere gebeurtenisse en die uiteindelike doel daarvan, behoort ook in 'n pastorale benadering na vore te tree. Dit behoort daarom geen verleentheid vir 'n pastor te wees om by geleentheid vir mense in lyding of nood te sê dat hy self nie antwoorde het op die vrae van die gebeure nie. 
Die pastor kan dit egter nie daarby laat nie. Dit is juis hier waar daar vanuit die lydingsteologie verrassende perspektiewe na vore tree. Vanuit hierdie perspektiewe vind mense dikwels dan ook die nodige troos, soos hierna in die skripsie sal blyk.

\subsection{Medelye}

'n Geslaagde teodisee kan een wees wat God ook as 'n lydende God sien. Dit beteken dat God nie onverstoorbaar is nie, maar gevoelig. Volgens Sarot (1995:157) is daar dikwels in die verlede 'n te skerp onderskeid tussen God en Christus getref, wat daartoe gelei het dat teoloë van mening was dat terwyl Christus gely het, God ongevoelig gebly het. Sarot (1995:158) is egter van mening dat God mee gely het, aangesien Christus se lyding nie van die Goddelike natuur losgemaak kan word nie. Christus se kruis is God se kruis, dit is die uiterlike teken van die innerlike kruis in die hart van God. Die troos van die kruis is volgens Sarot slegs ' $n$ werklikheid omdat God self hierin betrokke is.

Mense wat ly het 'n behoefte aan begrip en die ervaring dat hulle belangrik is. Deur empatie kan saam met lydendes getreur word en in 'n sekere mate kan hulle ervaring begrypend gedeel word. Talle voorbeelde bevestig die waarneming dat medelye lydendes kan help. Die vraag duik egter op: 'Wat maak medelye so vertroostend?' Die soorte lyding wat die meeste deur medelye verlig kan word, kan beskryf word as ernstige toestande van angs en benoudheid, wat 'n bedreiging is vir menslike kalmte, integriteit en die vervulling van voornemens (Sarot 1995:163). Hierdie dreigende karakter van lyding kan deur medelye verlig word. Gemoedsrus en integriteit is nie objekte buite die mens nie; inteendeel, dit is deel van menslike identiteit. Lyding bedreig met ander woorde menslike identiteit, dit verneder en doen afbreuk aan die kwaliteit van lewe, dit laat mense laag en vuil voel (Ps 22:7,15).

Dit is vanweë hierdie bedreiging van menslike waardigheid, dat medelye vertroostend kan wees. Die persoon wat medelye betoon wys daardeur dat hy nie onverskillig teenoor die verknorsing van die lydende staan nie - die lydende maak dus vir hom saak. Die vernederende aspek van lyding word dus deur die medelydende ontken. Op hierdie wyse word die menslike waardigheid van die lydende bevestig en sy selfrespek versterk, wat dit vir hom moontlik maak om sy lyding in 'n ander lig te sien (Sarot 1995:164).

Dit is waarom die hedendaagse teologie Goddelike medelye as empatie met menslike lyding, so hoog aanslaan (vgl Moltmann 1990:168-169). Die voordelige uitwerking van medelye lê nie soseer in die emosionele reaksie daarvan nie, maar daarin dat bewys gelewer word dat die lydende persoon vir die medelydende saak maak. Die verhouding tussen medelydende en lydende is 'n persoonlike verhouding, 'n verhouding van onderlinge gemeenskap en liefde. Die troos wat aan die lydende gebied word, be- 
staan daarin dat die bedreigde bestaan in die liefde van die medelydende veranker mag wees (Sarot 1995:164). Dit is die agting en respek wat die medelydende vir die lydende het, wat die lydende help om opnuut sy identiteit teenoor sy lyding te bevestig (Sarot 1995:165).

As Christus se lyding nie van die Goddelike natuur losgemaak kan word nie, dan beteken dit dat God self in Christus ons mede-lydende geword het. Dit is wat Pannenberg (1994:166) bedoel as hy sê dat God in en deur Christus se kruisiging, verantwoordelikheid aanvaar het vir die wêreld wat deur Hom gemaak is. Die mens, as God se skepsel, het sy vryheid misbruik en só in die nood (sondeval) tereg gekom. God distansieer Homself egter nie van die mens in sy verleentheid nie, maar betoon medelye deur selfs ' $n$ oplossing in en deur die Christusgebeure aan te bied.

\subsection{Die kruisgebeure as trinitariese gebeure}

Jürgen Moltmann is een van die teoloë wat tereg 'n trinitariese benadering ten opsigte van die kruisgebeure bepleit. Volgens Moltmann (1990:177) was God in Christus. Jesus se swakheid was God se swakheid, sy lyding was God se lyding: 'Glo jy nie dat Ek in die Vader is en die Vader in My nie?'. (Joh 14:10). Op grond van hierdie wedersydse inwoning van die Vader en die Seun, kan Jesus se lyding as Goddelike lyding beskou word. God se liefde is 'n liefde wat in staat is om te ly en wat ook daartoe bereid is. Kruisteologie word verkeerd verstaan, tensy begryp word dat dit eintlik die teologie van die pyn van God is, met ander woorde Goddelike mee-lye in die kruisgebeure (Moltmann 1990:178).

Die Drie-eenheid is betrokke in die beweging van selfoorgawe aan die kruis, maar in en deur Christus se lyding bereik dit verlore mense. Volgens Moltmann (1990:178179 ) is dit 'n gebrek aan begrip wat daartoe lei om te sê dat Een Persoon van die Drieeenheid gely het, en dat die Ander die lyding veroorsaak het. God veroorsaak volgens Moltmann nie Christus se lyding nie, en Christus is ook nie 'n gedweë en hulpelose slagoffer van lyding nie. In en deur Christus se selfoorgawe, soek God verlore skepsels op en betree só hulle verlatenheid, deur sy gemeenskap aan te bied.

Die Heilige Gees het ten volle in die mens Jesus gewoon en dit is deur die Gees dat die Seun Homself in gehoorsaamheid aan die Vader gee. In hierdie algehele toewyding tot op die punt van die dood, kom die Gees vry - Hy word bevry van die een besondere historiese figuur (Kasper 1976:252). Jesus se dood en opstanding bemiddel dus die koms of uitstorting van die Heilige Gees (Kasper 1976:252). Dit is hoe God verlore skepsels opsoek en van hulle sy kinders maak, met ander woorde broers en susters van sy Seun (vgl Joh 3:3-5; 15:14, 15; 17:8-10). 
Paulus sien in Jesus se oorlewering deur God, 'n prysgawe van die Seun ter wille van goddeloses en mense wat van God verlate is. God spaar dus nie sy eie Seun nie, maar wel goddeloses (Rom 8:31-32). Hierdie nie-spaar van die Seun, sy oorlewering, betrek ook die Vader. In die oorgawe van die Seun, gee die Vader Homself ook oor, hoewel nie op dieselfde wyse nie (Moltmann 1974:243). Jesus ly terwyl Hy in verlatenheid sterf, maar die Vader wat Hom oorlewer, ly of ervaar die dood van die Seun in die oneindige pyn van sy liefde vir die Seun. Die lyding en sterwe van die Seun verskil dus van die lyding van die Vader. Die Seun ly terwyl Hy sterf; die Vader ly aan die dood van sy Seun. Die pyn van die Vader is volgens Moltmann (1974:243) net so belangrik as die dood van die Seun. In sy afdaal na die hel verloor die Seun die Vader uit die $\infty \mathrm{g}$, en in sy oordeel verloor die Vader die Seun uit die oog. Die Vaderloosheid van die Seun weeg dus op teen die Seunloosheid van die Vader (Moltmann 1974:243).

Die poging van Moltmann om die Vader ook by die kruisgebeure te betrek, is merkwaardig, maar 'n waarskuwende woord van Van Niftrik (1953:132) is dalk hier gepas. Hy en talle voor hom het gewaak teen patripassianisme, naamlik die opvatting dat die Vader gely het. As die Seun feitlik presies dieselfde is as die Vader, moet die noodwendige gevolg wees dat die Vader self gely het. En volgens Van Niftrik is dit 'n absurditeit. Die onderskeid tussen Vader en Seun word in só 'n opvatting opgeoffer ter wille van die handhawing van eenheid, of dan 'n suiwer monoteistiese standpunt.

As die kritiek van Van Niftrik nie meer gehandhaaf kan word nie, dui dit op 'n belangrike klemverskuiwing in die lydingsteologie: Lyding word nie meer slegs tot Christus beperk nie, maar sluit nou die Vader in. Dit is immers wat beide Sarot en Moltmann met hulle betoë wou bereik. 'n Belangrike vraag hier is of hulle nie juis op hierdie wyse reg laat geskied aan die uitdrukking Immanuel nie, dit is, God met ons.

Dit is verder die moeite werd om daarop te wys dat daar gedeeltes in beide die $\mathrm{Ou}$ en Nuwe Testamente is, waar daar op so 'n wyse oor God gepraat word, dat dit nie altyd duidelik is of daar na die Vader of na die Seun verwys word nie (vgl Jes 9:5-6; Joh 1:1-3, 14; 20:26-28; Op 19:11-16; 21:22-23). Dit moet erken word dat ons hier voor die misterie van die Drie-eenheid stuit: Verskillende Goddelike 'Persone' word in die Skrif aan ons geopenbaar, en tog blyk dit Een en Dieselfde Wese te wees. Dit moet so wees, want die kerk het nog altyd bely dat dit God self is wat by die verlossing van die mens betrokke is.

Daarom kan saam met Moltmann (1974:244) gesê word, dat wat aan die kruis gebeur, iets is wat afspeel tussen God en God. Dit is 'n onvoorwaardelike liefde wat uitgaan van die pyn van die Vader en die dood van die Seun, wat verlore mense opsoek om in hulle die moontlikheid van nuwe lewe te skep (Moltmann 1974:245). As die 
Drie-eenheid as 'n gebeure van liefde in die lyding en dood van die Seun beskou word, dan is die Drie-eenheid nie 'n teruggetrokke groep in die hemel nie, maar 'n eskatologiese proses wat vir mense op aarde oop is, met sy wortels in die kruis van Christus (Moltmann 1974:249).

\subsection{Die kruisgebeure as straf}

Die teregstelling van Jesus van Nasaret aan 'n kruis, is een van die sekerste aspekte van sy lewe. Al vier evangeliste stem saam dat dit op die Vrydag van die Joodse pasga was, waarskynlik op 7 April 30 n C (Kasper 1976:113). Die Jode en Romeine het 'n besliste aandeel in Jesus se dood gehad, maar dit is eintlik bysaak, want dit was meteen 'n reddende daad deur God, sowel as selfprysgawe aan die kant van Jesus (Joh 10:18).

Wie die woord God uitspreek, bedoel tegelyk daarmee die kruis van Jesus Christus, want God word geken as die Een wat op hierdie besondere wyse gehandel het, en ontmoet word (Ott 1981:266). Die kruis van Christus is die teken van God se selfgewende liefde: God se identiteit, sy karakter as die Een wat die mens grensloos liefhet, manifesteer in die kruisgebeure as die selfopoffering van God (Ott 1981:260). Die verkondiging van verlossing en bevryding vir die mens deur die lyding en dood van Christus, staan in die sentrum van die Nuwe Testament (Moltmann 1977:85). Paulus wou niks anders verkondig nie as Christus, en Hom as gekruisigde (1 Kor 2:2). Vir Luther is die kruis van Christus 'n beslissende heilsgebeure (Ott 1981:259).

Jesus se kruisiging is nie deur vroeë Christene gesien as straf op sy eie sondes nie (Pannenberg 1994:423). Hierdie beskouing was slegs moontlik in die lig van die opstanding, want deurdat God Hom uit die dood opgewek het, het Hy Hom regverdig verklaar (Rom 1:4), ten spyte van die aanklagte wat tot sy teregstelling aanleiding gegee het. Deur die opstandingsgebeure blyk Jesus dus sondeloos te wees. As Hy dus nie vir sy eie sondes geboet het nie, kon Hy slegs vir dié van ander gesterf het (Pannenberg 1994:424).

Die onskuldige het dus die straf van die dood gely: 'Vervloek is elkeen wat aan 'n hout opgehang is' (Gal 3:13). Hierdie straf is die lot van hulle, in wie se plek Hy gesterf het (Pannenberg 1994:427). Hierdie plaasvervangende lyding - wat ook as die plaasvervangende lyding onder God se toorn oor die sonde beskou word - is gewortel in die solidariteit wat Jesus Christus met al die sondaars en hulle lot aanvaar het (Pannenberg 1994:427).

Jesus se uitroep aan die kruis: 'My God, my God, waarom het U My verlaat?' (Mark 15:34), is volgens Moltmann (1990:166) die oop wond van elke Christelike teologie, want bewustelik of onbewustelik word daar gepoog om antwoorde op hierdie vraag van Jesus te gee. Dit is alles pogings om teologiese betekenis aan sy dood te 
gee. God se swye, sy verberging van Homself, die verduistering van God, die dood van God, hel: Dit is alles beelde wat deur die loop van die geskiedenis vir hierdie onbegryplike gebeurtenis aan ons oorgelewer is (Moltmann 1990:167). Dit is pogings om ' $n$ afgrond te beskryf, die wegsink in 'n absolute niks. Die uniekheid van wat tussen Jesus en sy Vader afgespeel het, is iets wat aanvaar en as 'n geheimenis gerespekteer moet word (Moltmann 1990:167).

Volgens Van Wyk (1988:452) is God se vermoedelike afwesigheid, slegs een wyse van sy teenwoordigheid. Hoewel Jesus aan die kruis gedink het dat God Hom verlaat het, was Hy teenwoordig, handelend in sy vreemde werk. Saam met Van Wyk kan gesê word:

Hy was aanwesig in sy oordeel oor die sonde ... Die afwesigheid van God by die kruis is, agterna betrag, nie 'n liefdelose oorlaat van Jesus aan onmenslike lyding nie, maar sy liefdevolle oordeel oor die sonde van die wêreld .... Sy afwesigheid moet eerder die geloof versterk dat God wat ook die God van die oordeel is (en moet wees as Hy waarlik God is), die mens nie aan die konsekwensie van sy sondigheid, naamlik die ewige dood, oorlaat nie, maar sy toorn intertrinitaries laat uitwoed deur sy Seun te laat sterf, om in liefde sy gelowiges te red van die ewige dood.

(Van Wyk 1988:452-453)

Die verpletterende gedagte wat soms deur die gemoed van 'n sieke of lydende gaan, naamlik dat God besig is om met hom in die gerig te tree vanweë ' $n$ bepaalde misstap of oortreding, word deur bogenoemde standpunt van Van Wyk, weerlê. As God straf, speel Hy nie: Gerig en verdoemenis kom in al sy felheid in die kruisgebeure op Christus neer, sodat die mens, die skuldige, mag vrykom en lewe. Die swaarkry van 'n sieke kan daarom hoogstens as lyding beskou word en nooit as straf deur God nie.

\subsection{Versoening}

Die Skrif sien die mens nooit as 'n geïsoleerde individu voor God nie - sonde sowel as verlossing word altyd in hulle sosiale dimensies gesien (Kasper 1976:215). Die sondaar staan nie alleen nie, maar is deel van 'n groter geheel; sy verkeerde dade hou daarom 'n direkte gevaar in vir die gemeenskap, want solidariteit ten opsigte van sonde veronderstel 'n soort aansteeklikheid of besmetting (Kasper 1976:215). In die Ou Testament moes die gemeente hierdie solidaritieit met die sondaar, deur afsnyding verbreek. Versoening kon ook gedoen word deur plaasvervangende handelinge. Die beste 
voorbeeld is die oordrag van die sonde van mense op 'n bok, deur die plasing van hande op sy kop en om hom dan die woestyn in te jaag (Lev 16:20-22).

Solidariteit ten opsigte van verlossing veronderstel egter ook 'n soort aansteeklikheid. So seker as wat die sondaar in ou Israel andere sou besmet, net so seker sal die lig en bevryding van die versoening in Christus, andere aanraak en beïnvloed (vgl Matt 5:14-16).

Die Christelike teologie (Pannenberg 1994:403) het nog altyd die dood van Jesus op grond van Romeine 5:10 in terme van versoening verstaan: 'Aangesien ons, toe ons nog vyande was, deur die dood van sy Seun met God versoen is, staan dit soveel vaster dat ons, noudat ons versoen is, deur die lewe van sy Seun gered sal word' (my beklemtoning). Versoening veronderstel vyandskap (Engelbrecht 1978:280) - vyandskap tussen God en mens op grond van die mens se sonde en ongehoorsaamheid. Deur die loop van die geskiedenis is die dood van Jesus onder andere geïnterpreteer as die wegneem van hierdie vyandskap, en die vervanging daarvan met vrede en vriendskap. Versoening dui dus op 'n toestand van vrede en vriendskap tussen God en mens, op grond van die dood van Jesus (Weber 1983:186). Jesus word dus gesien as die outeur van 'n veranderde situasie tussen God en mens. As dit waar is, meen Pannenberg (1994:410) dat die dood van Christus as die werklike oorkoming van die sondeval, die dood en die vervreemding tussen God en mens beskou kan word.

Dit is wat bedoel word, wanneer daar oor Christus se dood as versoening vir menslike sonde gepraat word, want versoening verwyder die oortreding, die skuld en die gevolge (Pannenberg 1994:411). In versoening word die oortreders bevry van die skadelike gevolge van hulle dade, soos geillustreer deur die soenoffers van die $\mathrm{Ou}$ Testament (Lev 4-5). Die skuld word op die diere-offer oorgedra en daarmee tersyde gestel. Die skadelike gevolge van die sonde word só deur versoening tot niet gemaak. Die interpretasie van Christus se dood as versoening vir menslike sonde, veronderstel dat, soos God soenoffers daargestel het vir die oordrag van sonde op diere, so het $\mathrm{Hy}$ menslike sonde op Christus oorgedra met sy kruisdood (Pannenberg 1994:412).

Hierdie versoening, hierdie vrede en vriendskap is nie slegs vir 'n paar mense beskore nie: 'Die boodskap van versoening bestaan daarin dat God deur Christus die wêreld met Homself versoen het en die mense hulle oortredinge nie toereken nie' (2 Kor 5:19; my beklemtoning). Hierdie versoening kan nogtans nie as iets outomaties beskou word nie, want die mens word ook opgeroep om sy instemming daarmee te betuig: 'Ons smeek julle namens Christus: Aanvaar die versoening met God wat Hy bewerk het!' (2 Kor 5:20; my beklemtoning). Dit is in hierdie sin dat Paulus in Romeine 3:2526 van Christus se dood as versoening praat. Hy voeg egter die voorwaarde van die 
geloof daarby, want dit is slegs op grond van die geloof dat die mens in die versoenende effek van hierdie gebeurtenis kan deel (Pannenberg 1994:411).

Die offer van versoening wat deur die een kant aangebied word, moet deur die ander kant aanvaar word, voor daar sprake van versoening kan wees. Volgens Paulus ( 2 Kor $5: 11,20$ ) is die mens nie onaktief in die versoeningsgebeure nie, want hy bly ' $n$ persoon. Hy is 'n ontvanger, maar daar kan nie van blote passiwiteit sprake wees nie, want versoening is altyd 'n aktiwiteit waarin twee partye betrokke is (Weber 1983: 185). Volgens Pannenberg (1994:428) vind hierdie aanvaarding deur individue plaas, deur die toe-eiening daarvan deur middel van belydenis, doop en geloof. Hiersonder kan versoening nie aangedui word as 'n gebeurtenis wat deur die dood van Christus voltrek is nie.

\subsection{Plaasvervanging en verteenwoordiging}

Een van die vroegste belydenisse van die vroeë kerk, naamlik 1 Korintiërs 15:3-5, word gebruik om die dood van Jesus as 'n verteenwoordigende sterwe te interpreteer met die oog op die verlossing van mense (Kasper 1976:119). Daar is vroeg reeds besef dat as die interpretasie van Jesus se dood as 'n versoenende corgawe aan God, ter wille van mense, nie deur uitsprake uit en verwysings na die lewe en dood van Jesus self ondersteun word nie, sou die kern van die Christelike geloof gevaarlik na aan mitologie en valse ideologie kom (Kasper 1976:119). Dit sou beteken dat die vroeë kerk 'n betekenis aan Jesus se dood toegeken het, waarvan Hy self geen idee gehad het nie.

Daar word egter oortuigend deur Kasper (1976:120) aangetoon dat Jesus se hele lewe die stempel van 'n dienskneg gedra het en van een wat vir baie gely het. Geen grondige argument kan volgens hom aangevoer word teen die feit dat Jesus sy eie dood as 'n plaasvervangende en verlossende diens aan baie beskou het nie (Kasper 1976: 120). In sy verhouding tot sy Vader is Jesus se bestaan geheel en al gehoorsaamheid. Hy leef om God se wil te doen - dit is sy voedsel (Joh 4:34). In sy verhouding tot sy. medemens is sy bestaan geheel en al toewyding en plaasvervanging (Kasper 1976:217). Volgens die Grieke is selfhandhawing die hoogste goed, maar dit is Christus se natuur om vir ander te bestaan, met ander woorde in selfprysgawe (Kasper 1976:217). Hierdie selfprysgawe is nie bloot die selfprysgawe van 'n toegewyde persoon nie, maar besit eskatologiese kwaliteit, want dit is die selfprysgawe van Christus, die Seun van God. (Kasper 1976:209).

As Christus se selfprysgawe eskatologiese kwaliteit besit, beteken dit eindtydelike of ewige voordeel vir diegene vir wie Hy Homself prysgegee het. Mense wat ly besef dit nie altyd nie, en as hulle dit wel besef is hulle hoop en verwagting totaal op die toekoms gevestig. Dit strook egter nie met die Nuwe-Testamentiese beskouing van tyd 
nie, want hiervolgens is die ewige lewe nie iets wat eers aan die anderkant van die graf begin nie, maar reeds aan die duskant: 'En dit is die ewige lewe: dat hulle $U$ ken, die enigste ware God, en Jesus Christus, wat deur U gestuur is' (Joh 17:3). Om kennis van die Vader en die Seun aan lydendes deur te gee, is immers die roeping en taak van 'n pastor. As dit korrek hanteer word, is hierdie kennis nie slegs van teoretiese belang nie, maar van eksistensiële betekenis, want dit maak hier en nou vir die lydende saak.

Hierdie eksistensiële betekenis tree duidelik na vore in die Nuwe-Testamentiese verkondiging, wat die huper-formules, vir ons en vir baie tot hooftema van Jesus se geskiedenis maak (Kasper 1976:216). 'n Gedeelte waarna verwys kan word om eersgenoemde te illustreer is 1 Korintieërs 15:3: 'Die belangrikste wat ek aan julle oorgelewer het ... is dit: Christus het vir ons sondes gesterf, volgens die Skrifte' (my beklemtoning). As tweede illustrasie kan na Markus 10:45 verwys word: 'Die Seun van die mens het ook nie gekom om gedien te word nie, maar om te dien en sy lewe te gee as losprys vir baie mense' (my beklemtoning).

In beide gedeeltes het die formules vir ons en vir baie, 'n drievoudige betekenis: Ter wille van ons, tot ons voordeel en in ons plek. Al drie bogenoemde betekenisse word tegelyk veronderstel en bedoel as uitdrukking van Jesus se solidariteit met ons, as die kern van sy menslike bestaan (Kasper 1976:216). Paulus stel dat Christus deur sy dood die plek van sondaars ingeneem het: 'Christus was sonder sonde, maar God het Hom in ons plek as sondaar behandel' ( 2 Kor 5:21; my beklemtoning). Die idee van die omruil van plekke, word uitdruklik hier vermeld. Jesus Christus het met ons plekke geruil. Hy het Homself vrywilliglik met ons geïdentifiseer en ons plek ingeneem - ons het sy plek ingeneem. Die hele situasie is dus verander; Paulus noem hierdie omruiling van plekke versoening (Kasper 1976:216). Versoening beteken om die ander een te word. Christus, wat nie sonde geken het nie, is in ons plek as sondaar behandel; en ons wat sondaars was, het sondeloses, vrygespreektes, regverdiges geword (2 Kor 5:21; Gal 3:13).

Vir Pannenberg (1994:418) dra hierdie idee nog meer gewig as die uitdrukking in Romeine 5:6-8, naamlik dat Jesus sy lewe vir ons gegee het. Dat Jesus sy lewe vir ons gegee het, hoef nie noodwendig te beteken dat $\mathrm{Hy}$ die dood gesterf het, wat ons eintlik toegekom het nie. 'n Persoon wat iets vir ander mense doen, hoef nie noodwendig daardie mense vir wie hy dit doen, se eksistensiële posisie te betree nie (Pannenberg 1994:419). Maar dit is presies wat Paulus met die omnil van plekke in 2 Korintiërs 5: 21 bedoel. En in Romeine 8:3 verklaar hy dat verteenwoordiging in hierdie sin juis God se doel met die stuur van sy Seun was: '... deur sy eie Seun in dieselfde gestalte as die sondige mens te stuur; so het Hy die sonde in die sondige bestaan van die mens veroordeel' (my beklemtoning). 
Die loon en gevolg van die veroordeling van ons sonde, naamlik die dood, het op Christus neergekom wat ons posisie eksistensieel betree het en as ons verteenwoordiger, met ons plekke geruil het. Die menswording van die Seun van God en sy deelword van hierdie aardse bestaan, wat deur die sonde gekenmerk word, beteken dat Hy die plek van sondaars ingeneem het, sodat Hy hulle lot deelagtig kon word (Pannenberg 1994: 421).

Wat ons hier het, is medemenslike solidariteit waarin sommige, ander verteenwoordig (Pannenberg 1994:419). Die eerste Adam was ons verteenwoordiger daarin dat ons deur sy ongehoorsaamheid, sondaars geword het. Die tweede Adam, Christus, is egter ook ons verteenwoordiger daarin dat ons deur sy gehoorsaamheid vrygespreek is en nou met God versoen is (Rom 5:19). Die oordeel oor die sonde in die dood van Jesus, is die basis van versoening, maar die versoenende effek daarvan is nie slegs 'n objektiewe gebeurtenis van die verlede nie (Pannenberg 1994:428). Dit raak eers vir individue vrugbaar as hulle eie dood aan die dood van Christus gekoppel word (Pannenberg 1994:428). As Pannenberg korrek verstaan word, is sy bedoeling nie slegs die dood as die einde van 'n mens se aardse lewe nie, maar die dood as 'n sterwe vir die sonde. As Christus, as ons verteenwoordiger, vir die sonde gesterf het, moet ons ook daarvoor sterf, met ander woorde daarvoor dood wees (Fil 3:10). Pannenberg is van mening dat die versoenende effek van Christus se dood, slegs só vir individue van krag word. Wat in Christus se dood gebeur het, is nie outomaties op alle ander mense van toepassing nie. Dit vra uitdruklike stigting van gemeenskap met Hom, instemming met dit waarvoor Hy gesterf het (Pannenberg 1994:430). Dié vir wie plaasvervangend gely is, moet self ook nog sterf, maar hulle dood besit nou die moontlikheid om in die opstandingslewe te deel, wat reeds in Jesus aan die lig getree het (Rom 6:5). Ontvangers van die versoenende werking van die dood van Jesus, mag dus in die vertroue lewe dat hulle eie dood nie finale uitsluiting van God en sy lewe sal beteken nie (Pannenberg 1994:427). Hulle dood kry nou 'n betekenis wat dit nie vanself het nie - dit word 'n sterwe in hoop (Pannenberg 1994:430).

As ons iets vir ander mense doen wat hulleself behoort te gedoen het, of as ons ly wat hulle eintlik moes gely het, het ons 'n eksklusiewe beskouing van verteenwoordiging (Pannenberg 1994:429). Ons alleen doen wat gedoen moet word en hulle wat deur ons verteenwoordig word, hoef dit nie meer te doen nie. Volgens Pannenberg (1994: 429) is eksklusiewe verteenwoordiging egter nie volgens Nuwe-Testamentiese getuienis nie. Die versoenende sterwe van Christus is nie volgens hom ' $n$ betaling of offer aan God in die plek van andere nie. Dit beteken nie dat ander nie meer hoef te sterwe nie. Christus se dood daarenteen, verteenwoordig almal se dood voor God: '... dat een vir almal gesterwe het ... beteken dat almal gesterwe het' ( 2 Kor 5:14; my beklemtoning). 
Ons het egter ' $n$ inklusiewe beskouing van verteenwoordiging, as ons Jesus sien as die verteenwoordiger van die ganse mensdom: In Hom vind plaas wat in elke lid van die mensdom herhaal moet word (Rom 7:4,6). Sy gehoorsaamheid aan God en sy sterwe vir die sonde, is dus paradigmaties vir elkeen van ons (Pannenberg 1994:435).

Van eksklusiewe verteenwoordiging deur Christus is daar slegs sprake in die sin van die uniekheid van sy sterwe: Sy sterwe is 'n straf op ons sondes, iets wat slegs Hy kon dra. Inklusiewe verteenwoordiging deur Christus beteken dat ons onsself met Christus identifiseer, daarin dat ons ook vir die sonde sterf, soos Hy daarvoor moes sterf (Weber 1983:201). Op grond van die bogenoemde beredenering kan gestel word dat hierin 'n pastorale perspektief na vore tree, wat in enige gesprek met lydendes, van groot betekenis kan wees.

\section{KONKLUSIE}

Die vraag kan gestel word dat as Christus ons met God versoen het (Rom 5:10), as Hy met ons plekke omgeruil het en in ons plek deur God as sondaar behandel is ( 2 Kor 5:21), en as Hy vir ons sondes gesterf het (1 Kor 15:3), waarom ons nog dikwels moet ly. As 'n antwoord wel gewaag kan word, kan dit in die volgende rigting gedoen word: Die feit dat Christus plaasvervangend, in ons plek gely en gesterf het wil nie sê dat ons nie ook sal sterf nie. Hulle vir wie Christus gesterf het, moet self ook nog sterf. Christus se versoenende sterwe beskerm nie ons aardse lewe teen die dood nie dit bewaar ons wel vir die ewige lewe in die oordeel van God (Pannenberg 1994:420).

Die afleiding kan daarom heeltemal tereg gemaak word dat as ons aardse lewe deur die dood - wat die uiterste vorm van verganklikheid en sinloosheid is - beëindig sal word, dan sal ons ook nog onder die mindere tekens van verganklikheid, soos lyding en siekte, gebuk moet gaan. Die genoegsaamheid van Christus se plaasvervangende offer aan die kruis kom egter in gedrang as lyding en siekte as 'n straf deur God gesien word. Daar kan dan met reg gevra word waarom dit nog vir God nodig is om die mens vir spesifieke oortredings te straf, as Hy reeds sy straf in en deur die kruisgebeure van Christus voltrek het.

Die vroeë kerk het Christus se lyding en sterwe as plaasvervangend beskou. Die Geloofsbelydenis van Nicea ( 325 n C) stel dit só: 'Ons glo in ... een Heer, Jesus Christus ... wat ter wille van ons, die mense, en ter wille van ons saligheid, neergedaal het uit die hemel ... wat selfs vir ons gekruisig is onder Pontius Pilatus, gely het en begrawe is ....' (my beklemtoning). Die Apostoliese Geloofsbelydenis ( $150 \mathrm{n} \mathrm{C}$ ) stel dit nog sterker, deur daaraan toe te voeg: '... en neergedaal het na die hel ....' (my beklemtoning). God is aktief in die oorgee van sy Seun ter wille van die verlossing of behoud van mense (Joh 3:16). In hierdie gebeure is die Seun egter nie passief nie, 
want in sy geval is daar sprake van selfprysgawe (Joh 10:17, 18; Gal 2:20). Daar kan gesê word dat die Vader en die Seun in die kruisgebeure één is in hierdie oorgawe aan die mens (Moltmann 1990:174). Daarom is dit ondenkbaar dat 'n God, wat só, ter wille van mense gehandel het, enigsins kleinlik sal handel deur hulle vir spesifieke oortredings te straf. Straf is 'n eskatologiese handeling wat reeds plaasvervangend in Christus se kruisgebeure plaasgevind het - die verduistering van God, die dood van God, die swye van God, hel. Die Nuwe-Testamentiese getuienis dui egter ook daarop dat straf as eskatologiese handeling weer aan die einde van die tyd deur God voltrek sal word (vgl Matt 25:31-46; Luk 17:20-37; Joh 5:29; 2 Kor 5:10; Op 22:6-21).

Die tyd waarin ons nou leef is genadetyd en daarom nie 'n tyd waarin God vergeldend met mense omgaan nie. Dit is ' $n$ tyd waarin die versoeningsaanbod van die een party, God, aan die ander party, die mens, gemaak word; met ander woorde 'n tyd vir beslissing aan die kant van die mens. Lyding en siekte kan daarom in hierdie bedeling, in die lig van die plaasvervangende lyding en sterwe van Christus, nie as straf deur God beskou word nie - dit is eerder deel van die gebroke bedeling waarin ons tans nog leef en waaraan die ganse skepping onderworpe is.

Aan die meeste skrywers van die Ou Testament se uitsprake lê oënskynlik 'n monistiese beskouing ten grondslag (vgl Deut 32:39; 1 Sam 2:6,7; Job 1:8-12; Jes 45:57). Enkele gedeeltes is egter problematies, aangesien dit in die rigting van 'n dualisme neig (vgl in hierdie verband 2 Sam 24:1 en 1 Kron 21:1 met mekaar). Die Nuwe Testament huldig soms 'n monistiese beskouing (vgl Matt 10:29-31; Joh 19:10-11), maar soms ook 'n dualistiese een (vgl Matt 6:13; Mark 5:1-20; Luk 13:10-17). Dit wil tog voorkom of die reformatoriese kerk vir 'n monistiese beskouing gekies het, wat dan ook in sy belydenisskrifte uitgemond het (vgl NGB art 13; HK vr 27,28).

Dit is juis 'n monistiese uitgangspunt wat van die teodiseevraag so 'n turksvy maak, soveel so dat Ott (1981:226) dit 'n onbeantwoordbare vraag noem, en Pannenberg (1994:164) stel dat God se regverdigheid eers onomwonde by die eskatologie aan die lig sal tree. 'n Monistiese uitgangspunt veronderstel immers dat God in beheer is, dat $\mathrm{Hy}$ regeer - selfs al kom dit nie vir mense so voor nie. Dit is ook die rede waarom die wysheidsliteratuur tot versigtigheid maan om vanuit 'n corsaak-gevolgskema te dink, want God se gelukstoedelings aan mense is onbegryplik (Van Wyk 1988:455). God regeer, maar mense het nie insae in wat agter die skerms gebeur nie.

Volgens Berkouwer (1950:288) word die kwelling oor die onoplosbaarheid van die teodiseevraag, deur die geloof in Christus oorwin. Dit beteken dat iemand wat in Christus glo en wat op grond daarvan in die versoenende effek van sy sterwe deel, nie meer bekommerd is oor die onverklaarbaarheid van sekere negatiewe gebeure in sy lewe nie. Hy leef in die vaste oortuiging dat dit nie vergelding deur God is nie, want 
Christus vorm as ' $t$ ware die buffer wat die straf absorbeer, wat hom eintlik toegekom het: 'Dood, waar is jou angel?' (1 Kor 15:55). Daarom word Jesus Christus nou reeds deur die kerk as Heer en Verlosser erken en bely. Die gelowige leef in die oortuiging dat hierdie buffervorming deur Christus, nie eers by die eindoordeel van krag sal wees nie, maar reeds aan die duskant van die graf 'n deurslaggewende uitwerking het reeds nou handel God met hom nie volgens wat hy verdien nie, maar alleen op grond van Christus se verdienste. Dit is heeltemal verstaanbaar waarom die Reformatoriese kerk deur die loop van die eeue by die stelreël, solus Christus, dit is, Christus alleen, gehou het. Die ander stelreëls gaan natuurlik hiermee saam, omdat dit só met bogenoemde verweef is, dat dit nie alleen kan staan nie: Sola gratia (genade alleen), sola fidei (geloof alleen) en sola Scriptura (die Skrif alleen).

Die gelowige bely dat God regeer en dat Hy op 'n besondere wyse, tot voordeel van mense, in en deur sy Seun Jesus Christus gehandel het. Die gelowige is egter ook deeglik bewus van sy eie verantwoordelikheid. Bonhoeffer het êrens gesê dat die enigste manier om verantwoordelik voor God te leef, is om te leef asof Hy nie bestaan nie. Op die oog af klink dit onverskillig en skrikwekkend, maar hy wou juis daarmee volledige menslike verantwoordelikheid beklemtoon. Die mens moenie só leef asof God sekere goed in die lewe vir hom sal doen nie; inteendeel, hy moet só leef en werk asof alles van homself afhang. Tog rus die gelowige in die vaste wete en oortuiging dat God in Christus álles reeds vir hom gedoen het. Vanuit hierdie geborgenheid kan hy leef en werk en speel - ja, ook siek wees en ly, want Goddelike sorg en menslike verantwoordelikheid gaan hand aan hand; om die waarheid te sê, dit is so inmekaar vervleg dat dit moeilik van mekaar geskei kan word.

As die gelowige verantwoordelikheid vir sy eie lewe in lyding en siekte aanvaar, mag hy geduldig wees, omdat hy nie aan die toeval of die blinde noodlot uitgelewer is nie - dit is nog dieselfde God, die Vader van Jesus Christus wat oor hom regeer. Saam met Deist (1985:58) kan dus gekonkludeer word: '... met God hét ons die krag en vermoë om die koste van dissipelskap te betaal, of dit vreugde of leed is. Maar dan moet ons in die bewussyn van daardie almag ly en in die bewussyn van daardie troosvolle nabyheid medely met God se mense ....'

\section{Literatuurverwysings}

Berkouwer, G C 1950. De voorzienigheid Gods. Kampen: Kok. Blank, S H 1962. s v Wisdom. The Interpreter's Dictionary of the Bible. Broad, C D 1975. Leibniz: An introduction. London: Cambridge University Press. Clements, R E 1983. A century of Old Testament study. Rev ed. Guildford: Lutterworth. 
Deist, F 1985. Waarom God? Kanttekeninge by lyding. Roodepoort: Christelike Uitgewersmaatskappy.

Engelbrecht, B J 1978. Teologie in die kerk: Artikels en opstelle uit 'n kwarteeu van teologiese arbeid. Pretoria: HAUM.

Kasper, W 1976. Jesus the Christ, tr by V Green. New Jersey: Paulist Press.

Komp, D M 1992. A mystery story: Children, cancer and covenant. Theology Today XLIX/1, 68-74.

Leibniz, G W 1951. Theodicy: Essays on the goodness of God, the freedom of man and the origin of evil, tr by E M Huggar. London: Routledge and Kegan Paul.

Loader, J A 1989. Spreuke van Salomo, in Van Zyl, A H (red), Verklarende Bybel (1983), 684-692. Kaapstad: Lux Verbi.

Moltmann, J 1974. The crucified God: The cross of Christ as the foundation and criticism of Christian theology, tr by R A Wilson and J Bowden. London: SCM.

1977. The church in the power of the Spirit: A contribution to Messianic ecclesiology, tr by M Kohl. London: SCM.

- 1990. The way of Jesus Christ: Christology in Messianic dimensions, tr by $\mathbf{M}$ Kohl. New York: Harper.

Ott, H 1974. God, tr by I \& U Nicol. Atlanta: John Knox.

1981. Die Antwort des Glaubens: Systematische Theologie in 50 Artikeln. 3 Aufl. Stuttgart: Kreuz.

Pannenberg, W 1991. An introduction to systematic theology. Grand Rapids: Eerdmans.

- 1994. Systematic theology, vol 2, tr by G W Bromiley. Grand Rapids: Eerdmans.

Sarot, M 1995. Divine compassion and the meaning of life. Scottish Journal of Theology 48/2, 155-168.

Van Niftrik, G C 1953. Kleine Dogmatiek, 4e druk. Nijkerk: Callenbach.

Van Selms, A 1983. Job, dl II. Nijkerk: Callenbach. (POT.)

Van Wyk, I W C 1988. Die 'verleentheid' van die teoloog voor die teodiseeprobleem. HTS 44/2, 450-461.

Weber, O 1983. Foundations of dogmatics, vol 2, tr by D L Guder. Grand Rapids: Eerdmans.

Weiland, J S 1955. s v Theodicee. Encyclopedie van het Christendom: Protestants deel. 